\title{
AVAILABILITY OF SOME TROPICAL PLANTS AS ALTERNATIVE ROUGHAGE SOURCE IN RUMINANT FEEDING
}

\author{
Gbetolossi Thibaut GBAGUIDI ${ }^{1}$, Betül Zehra SARICICEK ${ }^{1 *}$ \\ ${ }^{1}$ Department of Animal Science, Faculty of Agriculture, Ankara University, 06120, Ankara, Turkey
}

\begin{abstract}
Roughages have vital importance in the diet of ruminants because they are cheap and absolutely necessary for digestive physiology. Ruminant nutrition requires quality feeds to obtain high amounts of product. As more than half of the business inputs are made up of feed expenses, the necessity of high-quality roughage sources, which are cheaper compared to concentrate, arises. The high quality of roughage means that the amount of mixed feed that can be put into the ruminant ration to meet the nutrient require ment is less. Thus, the cost of the product to be obtained will decrease and the net profit will increase. Since the leaves of some plants grown in the tropical region and the fruits and shells that cannot be used as human food are not utilized, they cause environmental pollution, and the feed cost cannot be reduced because the vegetable waste is not used in animal feeding. Many tropical plant leaves and waste are rich in protein and crude fiber. Crude protein levels in the leaves of some tropical plants can be up to $30 \%$. The usability of tropical plant leaves and fruit peels, which are rich in nutrients, as roughage has not been adequately studied. These plants can be used as an alternative roughage source for ruminants in times of shortage of quality roughage and in times of famine, increasing animal production and preventing problems in the environment. The purpose of this review is to examine the possibilities of using leaves and fruits and wastes of some tropical plants (Guava, papaya, banana, mango, pineapple, cassava, moringa and avocado) as an alternative roughage source in ruminants.
\end{abstract}

Keywords: Ruminant, Tropical plants, Roughage

*Corresponding author: Department of Animal Science, Faculty of Agriculture, Ankara University, 06120, Ankara, Turkey

E mail: zsaricicek@ankara.edu.tr (B.Z. SARICICEK)

Gbetolossi Thibaut GBAGUIDI (iD) https://orcid.org/0000-0002-3866-7121

Betül Zehra SARICICEK (iD) https://orcid.org/0000-0003-2138-793X

Received: February 03, 2021

Accepted: June 08, 2021

Published: July 01, 2021

Cite as: Gbaguidi GT, Saricicek BZ. 2021. Availability of some tropical plants as alternative roughage source in ruminant feeding. BSJ Agri, 4(3): 107-111.

\section{Introduction}

One of the main factors limiting animal production in the world and especially in developing countries is the high cost of feed inputs. Roughages are bulky feeds rich in crude fiber (CF), with low digestibility, energy density and nutrient composition. One of the most important problems to be solved in the feeding of ruminants is to meet the quality, cheap and easy to obtain roughage requirement of the animals. Roughage is essential for meeting the life and productivity needs of animals economically and for rumen physiology (Saricicek, 2007). In case the needs of animals cannot be met with fodder crop (high quality roughages), it is tried to be met with low quality roughages such as hay, stalk, husk and cut. In this case, the energy, protein and mineral needs of ruminants that cannot be covered with these feeds are met with expensive concentrate feeds. High use of concentrated feed in animal nutrition increases the costs of animal products and causes some metabolic disorders (Gemalmaz et al., 2016).

Some subtropical and tropical plants grown in tropical climates are grown in the Mediterranean region in Turkey. Recently, there has been increased interest in the use of tropical plants as feed for animal nutrition due to the richness of nutrient contents. The importance of tropical plants for animal production is that leaves, flowers, boughs, seeds, fruits and pods can be used by animals as concentrated feed or roughage. There are a variety of tropical legume plants that can be used as a protein source in the diet of ruminants. Tropical legumes are very important sources in terms of their seeds and the amino acid (AA) contents. However, it also has disadvantages such as being produced in small quantities, being used directly as human food and requiring expensive processing to be used in animal feed. Plants grown in the tropics have the potential to produce large amounts of leaves rich in nitrogen compounds on farms, and this potential can be an alternative roughage source to meet the roughage needs of ruminants. In some tropical regions (Benin, Niger etc.) where pastures are insufficient, the leaves of shrubs and trees that are rich in tannins and agricultural industry by-products (bark, pulp) are used as feed. Fadiyimu et al. (2010) state that the potential of using wastes such as tropical plants, leaves of trees and fruit pods as feed sources in animal feeding should be investigated in places where forage cultivation is insufficient. Tree branches and leaves can be an important part of the diet for ruminants such as goats, sheep and deer (Kamalak et al., 2005). Tree leaves, which are in the class of roughages, are materials that can be obtained from various trees grown in or around livestock enterprises. Especially sheep and goats fondly 


\section{Black Sea Journal of Agriculture}

consume tree leaves. However, very little is known about the nutritional and fodder value of these trees, shrubs and leaves, some of which have traditionally been used for many years. It will be very useful to reveal the nutritional values of branches and leaves, which have not been studied before.

In this review, the potential of some tropical plant leaves and wastes to be used as roughage sources in ruminant feeding is discussed in order to reduce the cost of feed and to prevent environmental pollution in areas where tropical plants (Guava, papaya, banana, mango, pineapple, cassava, moringa and avocado) are grown, as there is a shortage of forage due to the lack of forage crop cultivation in many tropical countries.

\section{Guava (Psidium guajava L.)}

Guava (Psidium guajava L.) belongs to the genus Psidium of the Myrtaceae family. Guava (Psidium guajava L.), also known as the apple of the tropics, is native to tropical Central America that extends from Mexico to North and South America, but also grows in other tropical and subtropical regions around the World. This fruit tree is an evergreen shrub-type small tree, 3-10 $\mathrm{m}$ tall (Gonzalez-Gaona et al., 2010). Guava flowers are fragrant and a good source of nectar for bees. In addition, guava leaves are reported to be effective in medicine against digestive system, respiratory tract, mouth / tooth and skin infections, diabetes, cardiovascular / hypertension, cancer, gynecological diseases, pain, fever, liver and kidney problems (Daswani et al., 2017). Guava fruits are extremely delicious. It is stated that the fruits of guava trees grown on pastures in tropical regions are consumed by farm animals, and up to $11 \mathrm{~kg}$ of fresh guava can be given daily to cattle (Somarriba, 1985). Guava waste is made from shells, seeds and stone cells in various proportions. The seeds contain moderate levels of ether extract (14\%) and protein (15\%), rich in crude fiber $(42 \%)$. Stone cells are rich in lignin (37\%) and cellulose (54\%) (El Boushy et al., 2000). Wastes are poor in protein (7-11\%) and rich in crude fiber (ADF 48-70\%), especially lignin (16-22\%) in dry matter (DM). Cattle, sheep and goats traditionally consume guava leaves in Hawaii and South Africa. Guava leaves have weak to moderate protein (10-14\% DM) and high fiber content (ADF 27-39\% DM). In a study conducted in Thailand, it was determined that the DM and protein degradability in guava leaves are high (71\%) and it is a high-value feed for cattle (Paengkoum et al., 2012). Al-Sagheer et al. (2018) stated that when $25 \%$ of guava leaves are used in the diet, there is no harmful effect on ruminal degradability of nutrients and may be an alternative contribution in reducing $\mathrm{CH}_{4}$ production. Hassan et al. (2016) state that dried guava wastes can be used effectively in the diet at a rate of $20 \%$ without adversely affecting the performance, digestibility, carcass characteristics or health parameters of Ossimi lambs.

\section{Papaya (Carica Papaya)}

Carica papaya L. (melon tree) belongs to the Caricaceae family. It is widely grown in Mexico and Central and South America, the Caribbean and Southeast Asia and Africa. The papaya tree is a perennial unbranched tree that grows up to $10 \mathrm{~m}$, with large leaves and clusters of fruits. Papaya fruits are delicious, and leaf and fruit byproducts can also be used in animal nutrition. In tropical countries, papaya leaves and pods are fed to animals as fresh and dried by growers. Papaya leaf has high protein content (23.9\%) and low fiber (10.5\%) ratio (Jayanegara et al., 2013). It has been stated by Melesse et al. (2018) that papaya by-products are a good source of energy for ruminants as they are rich in carbohydrates, and leaves are a good source of protein.

\section{Mango (Manguifera indica)}

Mango (Mangifera indica L.) is a tree grown for its fruit from the Anacardiaceae family. Mangoes are grown in South Asia, East Asia, East Africa, Brazil, the West Indies and Mexico. Mango Tree, has begun to grow in coastal areas like Antalya, Mersin in Turkey (Gübbük et al. 2017). The mango tree can stay green throughout the year. Mango leaves are delicious for ruminants and are loved to be consumed. $\mathrm{CP}$, ash, ether extract, neutral detergent fiber (NDF), acid detergent fiber (ADF) and acid detergent lignin (ADL) of mango leaves were found to be $13.60,12.61,3.92,35.32,34.98$, and $12.86 \%$, respectively (Jhaumeer et al., 2018). Therefore, it can be used as fresh and dried for animal feeding. Kumar et al., (2011) determined that mango leaves have the potential to inhibit methane formation in the rumen. It has been concluded that when $6 \%$ of mango leaves are used in lamb ration, gas and methane emission is significantly reduced, so that it can be used in lambs' rations at the rate of $6 \%$ without any harmful effects (Hassan et al., 2020).

\section{Pineapple (Ananas comosus)}

Pineapple (Ananas comosus (L.)) is from the Bromeliaceae family. Pineapple fruit canned producers are mostly in Asian countries, including Thailand, the Philippines, Indonesia, and Malaysia. In Africa, Kenya, Benin and Nigeria are also important producers (Achigan-Dako et al., 2014). Pineapple fruit is very sweet, it is an excellent source of vitamins and minerals. It is a very rich fruit especially in terms of $\mathrm{Mn}, \mathrm{B} 1$ and $\mathrm{C}$ vitamins. In addition to fruits, high-quality leaves are produced in large quantities that can be used as roughage for ruminants (Wakasa, 1989). Pineapple leaves are generally given to cattle by cutting. Pineapple leaves can also be used fresh, dried or silaged in ruminant diets. Pineapple leaves are low in crude protein content (4 to $7 \%$ DM) but very rich in fiber (NDF 58-73\% DM) (Heuzé and Tran, 2015). Pineapple leaves are suitable for dairy cows due to their high fiber content, but it must be chopped before use (Buliah et al., 2018). When pineapple 


\section{Black Sea Journal of Agriculture}

leaves were fed to beef cattle with fresh herbs or total mixed rations, it was determined that feed consumption and daily live weight increased, so the producer made more profit (Prachyalak et al., 2001). Since the silage of pineapple leaves is low in protein and very rich in fiber, it can easily be given to ruminants 15-20 kg per day (Göhl, 1982). It has also been revealed that silage made from pineapple fruit residues will be an alternative to traditional green food, reducing the cost of feed, and also helping to prevent environmental pollution from pineapple fruit waste (Elias et al., 2017).

\section{Banana (Musa spp)}

Banana (Musaceae) is a family belonging to the order Zingiberales. It is grown in tropical and subtropical regions in Asia, Africa and Australia, the Philippines, the Pacific Islands, West Africa, the Caribbean and Central America. In Turkey it is mostly cultivated between Bozyazı and Anamur. Banana protein, cellulose and carbohydrates are especially high in sugar.

Banana leaves have high moisture content $(85 \%)$ and low protein content $(10-17 \%)$. The body of the tree has a low protein content (2.8-7.6\%) and a high-moisture content (92-95\%). Banana peel is rich in starch, sugar, cellulose, minerals ( $\mathrm{K}, \mathrm{P}, \mathrm{Ca}$ and $\mathrm{Na}$ ) and some vitamins, except for its high moisture (73.8\%) content (Bouafou et al., 2012). Since banana fruit has a high moisture and carbohydrate content it causes digestive disorders. Therefore, fresh banana should not be used less than $70 \%$ in the ration and should not exceed $8 \%$ of live weight. $5 \mathrm{~kg}$ should be given to heifers for $100 \mathrm{~kg}$ body weight (Geoffroy, 1985). In the study conducted with rams, the dry matter digestibility of fresh green banana fruit and silage was determined as $66.4 \%$ and $68.2 \%$, respectively. It is suggested that banana peel can be used in ruminant rations with a profit of $7.5 \%$ (Gourdine et al., 2011). It is claimed that in ruminant rations where the digestibility of banana leaves is around $65 \%$, it can be given to dairy cows at a rate of $15 \%$ per day, and that ruminants can meet 60 to $80 \%$ of their total needs from banana leaves, even at a very early age (Geoffroy, 1985).

\section{Cassava (Manihot esculenta)}

Cassava (Manihot esculenta) is from the Euphorbiaceae family. Cassava is native to South America and is widely grown in tropical and subtropical regions, including subSaharan Africa and South East Asia. Cassava is grown for tubers that are used as a starch source. Cassava ruminal is a suitable feed for ruminants in terms of in vitro fermentation and organic matter digestibility. DM, CP, CF, EE and ash content of Cassava leaf are 93.0, 21.0, 25.0, $0.55,8.5 \%$ (in DM), respectively (Ravindran, 1993). It is suggested that cassava leaves can be a valuable feed for animals, but the leaves can be fed fresh, but dried or used as silage is more appropriate (Phengvilaysouk et al., 2008). When $50 \%$ cassava leaves were used in dairy cattle rations, it had a positive effect on DM consumption, body weight gain, milk production and milk fat content and the by-pass protein effect was also found to be high (Wanapat, 2002). It has been determined that the body weight gain, food digestibility and carcass quality of West African Dwarf rams are increased when cassava leaves are used in feed at a rate of $20 \%$ (Odusanya et al., 2017). Harun et al. (2017) suggest that $50 \%$ of cassava leaves can be used to increase the nutritional value of feed in the diet of malnourished goats. Kavana et al. (2005) stated that cassava leaves are more suitable to be used as silage, and up to $35 \%$ cassava leaves can be used to provide by-pass protein to silage with urea and molasses. It has been determined that cassava silage increases rumen fermentation, feed consumption, milk yield and quality in dairy cows (Wanapat et al., 2018). Noviadi et al. (2017) found that cassava leaves silage increased nutrient digestibility in goats.

\section{Moringa (Moringa oleifera)}

Moringa (Moringa oleifera Lam.) is a tropical tree species plant from the Moringaceae family. Moringa is a plant grown in a wide area from the southern hills of the Himalayas to Africa, the Caribbean Islands and Central America, India, Ethiopia, the Philippines and Sudan. Moringa, which is used for human food, is also used as a medicinal plant, and has an area of use in animal nutrition (Falowo et al., 2018).

Moringa is delicious and has a high nutritional value. Moringa leaves contain $412.0 \mathrm{~g} / \mathrm{kg}$ crude fat, $211.2 \mathrm{~g} /$ $\mathrm{kg}$ carbohydrate, and $44.3 \mathrm{~g} / \mathrm{kg}$ ash with $21.8 \%$ crude protein, 22.8\% ADF and 30.8\% NDF (in DM) (Sanchez et al. 2006). Moringa leaves are consumed by cattle, sheep and goats in Cuba and Venezuela. When Moringa leaves are given to growing goats alone or as an addition to the diet, it has been observed that daily feed consumption gives better results compared to leucaena (Leucaena leucocephala) or gliricidia (Asaolu et al., 2012). Moringa leaves have the highest crude protein digestibility (CPD), followed by branches and roots Moringa leaves have been found to increase daily body weight and digestibility of feed when added up to $50 \%$ to low quality feeds (Aregheore, 2002). According to Moyo et al. (2014), meat quality improves when moringa leaves are given to growing goats. According to Li et al. (2017), Moringa leaves have the highest crude protein digestibility (CPD), followed by branches and roots. The root CPD was higher than DM and OM. It is suggested that the leaves of moringa can be given alone, the branches should be mixed with feed with high nutrient content, and the roots should not be fed to cows.

\section{Avocado (Perseae Gratissimae)}

Avocado (Persea americana) is a tree belonging to the laurel family. Avocado is grown commercially in Central and South America, the West Indies, Polynesia, Philippines, Australia, New Zealand, Madagascar, Mauritius, Madeira, Canary Islands, Algeria, South Africa, 


\section{Black Sea Journal of Agriculture}

southern Spain and southern France, Sicily, Crete, Israel, Egypt and tropical Africa. The fruit of the avocado plant is also known as "American pear" because it resembles pear (Knight, 2002).

As well as the benefits of the avocado fruit, the leaves of this fruit have many benefits and are used in animal nutrition. In addition, avocado leaves are rich in potassium and vitamin B6. Leaves are high in dry matter (94.67\%), protein $(25.54 \%)$, ether extract (4.01\%), ash (19.38\%) and crude fiber (38.40\% in DM) (Arukwe et al., 2012). Since avocado leaves and peel contain persin, fresh feeding of the leaves can cause poisoning and death, so the leaves should be dried or silaged (Yamassaki et al., 2017). De Evan et al. (2020) reported that Avocado vegetable waste (husk-pulp), which is released in large amounts, can also be used as a source of roughage in ruminant feeding. It was concluded that when avocado wastes (pulp and shell mixture) are added to dairy goats' rations, it can improve the quality of milk fatty acid profile without negatively affecting milk yield (Velarde ve ark., 2020).

\section{Conclusion}

Although many tropical plant leaves and waste have high nutritional values and flavors, in some countries they are partially used as animal feed. Fruit peels, pulp and leaves of many tropical plants grown as human food that are not used as human food are generally not utilized and cause environmental pollution. These tropical plant wastes can be used as an alternative roughage source in ruminant feeding when there is a shortage of feed or when there is excess waste. The use of leaves and wastes with high nutritional value as a source of roughage in ruminant feeding will result in meeting the nutritional needs of animals cheaper. If these wastes are encouraged to be used as roughage in ruminant feeding, both animal production will increase, and feed costs of producers will be reduced. On the other hand, environmental pollution due to wastes will be prevented.

In conclusion, under the light of the literature reports, it can be said that plant leaf and fruit wastes (Guava, papaya, banana, mango, pineapple, cassava, moringa and avocado) grown in tropical regions will be evaluated as a source of roughage in ruminant feeding and will contribute to the solution of quality roughage problem.

\section{Author Contributions}

All authors have equal contribution and all authors reviewed and approved the manuscript.

\section{Conflict of Interest}

The authors declare that there is no conflict of interest.

\section{References}

Achigan-Dako EG, Sogbohossou OE, Maundu P. 2014. Current knowledge on Amaranthus spp.: research avenues for improved nutritional value and yield in leafy amaranths in sub-Saharan Africa. Euphytica, 197(3): 303-317.
Al-Sagheer AA, Elwakeel EA, Ahmed MG, Sallam SM. 2018. Potential of guava leaves for mitigating methane emissions and modulating ruminal fermentation characteristics and nutrient degradability. Environ Sci Pollution Res, 25(31): 31450-31458.

Aregheore EM. 2002. Intake and digestibility of Moringa oleifera-batiki grass mixtures by growing goats. Small Rum Res, 46(1): 23-28.

Arukwe U, Amadi BA, Duru MKC, Agomuo EN, Adindu EA, Odika PC, Lele KC, Egejuru L, Anudike J. 2012. Chemical composition of Persea americana leaf, fruit and seed. Int J Rec Res Appl Stud, 11(2): 346-349.

Asaolu V, Binuomote R, Akinlade J, Aderinola O, Oyelami O, 2012. Intake and growth performance of West African Dwarf Goats fed Moringa oleifera, Gliricidia sepium and Leucaena leucocephala dried leaves as supplements to cassava peels. J Biol Agric Health Care, 2(10): 76-88.

Bouafou KGM, Konan BA, Kouame KG, Kati-Coulibally S. 2012. Les produits et sous-produits du bananier dans l'alimentation animale. Int J Biol Chem Sci, 6(4): 1810-1818.

Buliah N, Jamek S, Ajit A, Abu R. 2018. Production of dairy cow pellets from pineapple leaf waste. In: Proceedings of the AIP Conference, 11-13 December, Penang, Malaysia, 2124(1): 020048.

Daswani PG, Gholkar MS, Birdi TJ. 2017. Psidium guajava: A single plant for multiple health problems of rural Indian population. Pharmacognosy Rev, 11(22): 167.

De Evan T, Vintimilla A, Molina-Alcaide E, Ranilla MJ, Carro MD. 2020. Potential of recycling cauliflower and romanesco wastes in ruminant feeding: In vitro studies. Animals, 10(8): 1247.

El Boushy AR, Van der Poel AF. 2000. Fruit, vegetable and brewers' waste. In Handbook of Poultry Feed from Waste. Springer, Dordrecht, Nederland. pp: 173-311.

Elias AIK, Alves KS, Oliveira LRS, Cutrim DO, Mezzomo R, Pontes VP, Gomes DI. 2017. Carcass yield, cuts and body components in lambs fed a pineapple by-product silage diet. African J Agri Res, 12(28): 2351-2357.

Fadiyimu AA, Alokan JA, Fajemisin AN. 2006. Digestibility, Nitrogen balance and haematological profile of West African dwarf sheep fed dietary levels of Moringa oleifera as supplement to Panicum maximum. J American Sci, 6(10): 634-643.

Falowo AB, Mukumbo FE, Idamokoro EM, Lorenzo JM, Afolayan AJ, Muchenje V. 2018. Multi-functional application of Moringa oleifera Lam. in nutrition and animal food products: A review. Food Res Int, 106: 317-334.

Garcia DE, Medina M G, Cova LJ, Soca M, Pizzani P, Baldizan A, Dominguez CE. 2008. Acceptability of tropical tree fodder by cattle, sheep and goats in Trujillo state, Venezuela. Zootecnia Trop, 26(3): 191-196.

Gemalmaz E, Bilal T. 2016. Alternatif kaba yem kaynakları. Lalahan Hayv Araş Enst Derg, 56(2): 63-69.

Geoffroy F. 1985. Utilisation de la banane par les ruminants. Revue de Elevage et Méd Vét des Pays Trop, 38: 92-96.

Göhl B. 1982. Les aliments du bétail sous les tropiques. FAO, Division de Production et Santé Animale, Roma, Italy.

Gonzalez-Gaona E, Padilla-Ramirez JS, Lozano-Gutierrez J, España-Luna MP, Velásquez-Valle R, Gallegos-Morales G, Cepeda-Siller M. 2010. Evaluation of Mexican guava germplasm against root knot nematodes. Acta Horticult, (849): 363-368.

Gourdine JL, Fanchone A, Alexandre G, Marie-Magdeleine C, Calif E, Fleury J, Renaudeau D. 2011. Le bananier et ses produits dans l'alimentation animale. Systèmes durables de 


\section{Black Sea Journal of Agriculture}

production et de transformation agricoles aux Antilles et en Guyane. (16) 2011; CIAG 2011 Carrefours de l'innovation agronomiques, Lamentin, Guadeloupe, France, 03 November 2011, 181-192.

Gübbük H, Biner B, Dal B, Yıldırım I, Daşkın D, Buhur L. 2017. Değişik tropik meyve türlerinin Antalya koşullarında adaptasyonu üzerine araştırmalar. TAGEM Proje Kesin sonuç raporu, Antalya, Turkey.

Harun NLA, Alimon AR, Jahromi MF, Samsudin AA. 2017. Effects of feeding goats with Leucaena leucocephala and Manihot esculenta leaves supplemented diets on rumen fermentation profiles, urinary purine derivatives and rumen microbial population. J App Anim Res, 45(1): 409-416.

Hassan M, Ding W, Shi Z, Zhao S. 2016. Methane enhancement through co-digestion of chicken manure and thermooxidative cleaved wheat straw with waste activated sludge: AC/N optimization case. Bioresource Tech, 211: 534-541.

Hassan TM, Ahmed-Farid OA, Abdel-Fattah FA. 2020. Effects of different sources and levels of tannins on live performance and antioxidant response of Ossimi lambs. The J Agri Sci, 158(4): 339-348.

Heuzé V, Tran G. 2015. Papaya (Carica papaya) fruits, leaves and by-products. Feedipedia, a programme by INRAE, CIRAD, AFZ and FAO.

Jayanegara A, Marquardt S, Wina E, Kreuzer M, Leiber F. 2013. In vitro indications for favourable non-additive effects on ruminal methane mitigation between high-phenolic and highquality forages. British J Nutri, 109(4): 615-622.

Jhaumeer Laulloo S, Bhowon MG, Soyfoo S, Chua LS. 2018. Nutritional and biological evaluation of leaves of Mangifera indica from Mauritius. J Chemistry, 2018: 6869294.

Kamalak A, Canbolat Ö, Gürbüz Y, Özay O, Erer M, Özkan ÇÖ. 2005. Kondense taninin rumimant hayvanlar üzerindeki etkileri hakkında bir inceleme. KSÜ Fen ve Müh Derg, 8(1): 132-137.

Kavana PY, Mtunda K, Abass A, Rweyendera V. 2005. Promotion of cassava leaves silage utilization for smallholder dairy production in Eastern coast of Tanzania. Livest Res Rural Dev, 17(4): 43.

Knight JrRJ. 2002. History, Distribution and Uses. In: A.W. Whiley, B.Schaffer And B.N. Wolstenholme (Eds) The Avocado: Botany, Production and Uses; Cabi Publishing, India. pp: 1-10.

Kumar A, Duhan JS. 2011. Production and characterization of amylase enzyme isolated from Aspergillus niger MTCC-104 employing solid state fermentation. Intern J Pharam Biol Sci, 2: B250-B258.

Melesse A, Steingass H, Schollenberger M, Rodehutscord M. 2018. Component composition, in vitro gas and methane production profiles of fruit by-products and leaves of root crops. The J Agri Sci, 156(7): 949.

Moyo B, Masika BJ, Muchenje V. 2014. Effect of feeding Moringa (Moringa oleifera) leaf meal on the physico-chemical characteristics and sensory properties of goat meat. South Afric J Anim Sci, 44(1): 64-70.

Noviadi R, Zairiful Z, Candra AA. 2017. Improvement of carbon- to-nitrogen $(\mathrm{c} / \mathrm{n})$ ratio by making cassava leaf silage and its implications in digestibility in goat. Bangladesh J Vet Medicine, 15(2): 127-132.

Odusanya LQ, Fasae OA, Adewumi OO, James IJ. 2017. Effect of cassava leaf meal concentrate diets on the performance, haematology and carcass characteristics of West African Dwarf lambs. Archivos de Zootecnia, 66(256): 603-609.

Paengkoum P, Traiyakun S, Khotsakdee J, Srisaikham S, Paengkoum S. 2012. Evaluating the degradability of the guava and jack fruit leaves using in sacco technique and three-step techniques. Pakistan J Nutr, 11(1): 16-20.

Phengvilaysouk A, Wanapat M. 2008. Study on the effect of harvesting frequency on cassava foliage for cassava hay production and its nutritive value. Livestock Res for Rural Dev, 20(9).

Prachyalak P, Poatong S, Wanasitchaiwat V. 2001. Utilization of pineapple crowns as a roughage for fattening cattle. Annual Report on Animal Nutrition Division 2001, Department of Livestock Development. Ministry of Agriculture and Cooperatives, Thailand.

Ravindran V. 1993. Cassava leaves as animal feed: potential and limitations. J Sci of Food and Agri, 61(2): 141-150.

Sanchez NR, Ledin S, Ledin I. 2006. Biomass production and chemical composition of Moringa oleifera under different management regimes in Nicaragua. Agroforestry Sys, 66(3): 231-242.

Sarıçiçek BZ. 2007. Küçükbaş ve Büyükbaş Hayvan Besleme. OMÜ. Ziraat Fakültesi, Samsun, Türkiye Yay. No: 37, Ders Kitabı. Samun, Turkey. pp: 435.

Somarriba E. 1985. Guava trees (Psidium guajava L.) in pastures. 2. Fruit consumption and seed dispersion. Turrialba, 35(4).

Velarde EDA, Martínez DLP, Salem AZ, García PGM, Berasain MDM. 2020. Antioxidant and antimicrobial capacity of three agroindustrial residues as animal feeds. Agroforestry Sys, 94(4): 1393-1402.

Wakasa K. 1989. Pineapple (Ananas comosus L. Merr.). Biotechnology in Agriculture and Forestry, Vol. 5 'frees II (ed. by Y. P. S. Bajaj) (C) Springer-Verlag Berlin Heidelberg, Germany.

Wanapat M, Phesatcha K, Viennasay B, Phesatcha B, Ampapon T, Kang S. 2018. Strategic supplementation of cassava top silage to enhance rumen fermentation and milk production in lactating dairy cows in the tropics. Tropical Anim Health and Prod, 50: 1539-1546.

Wanapat M. 2002. The role of cassava hay as animal feed. In: Research and Development in Asia: Exploring New Opportunities for an Ancient Crop, R. H. Howeler (ed.), Proc. 7th regional cassava workshop.

Yamassaki FT, Campestrini LH, Zawadzki-Baggio SF, Maurer JBB. 2017. Avocado leaves: influence of drying process, thermal incubation, and storage conditions on preservation of polyphenolic compounds and antioxidant activity. Int J Food Prop, 20(S2): S2280-S2293. 